\title{
石狩川の最初の治水計画および効果の検証 EFFECTS OF THE FIRST FLOOD CONTROL PLAN AND RIVER IMPROVEMENTS ON THE ISHIKARI RIVER BASIN
}

\author{
鈴木 英一 1 ・山口 里実 2 谷 育美3 \\ Eiichi Suzuki, Satomi Yamaguchi, Ikumi Tani
1フェロー会員 北海道大学特任教授 大学院工学研究院（干060-8628 札幌市北区北13条西8丁目）
2正会員 北海道大学特任准教授 大学院工学研究院（干060-8628 札幌市北区北13条西8丁目） \\ 3 札幌市 建設局 下水道施設部（干062-0906札幌市豊平区豊平6条3丁目2-1）
}

In 1869 the Meiji Government launched the policy of encouraging migration to Hokkaido and started reclamation of the Ishikari River Basin. In September 1898, when farmland reclamation had started to expand, the Ishikari River was hit by an unprecedented heavy flood that resulting in catastrophic damage and 112 fatalities. This disaster prompted surveys for flood control. Okazaki et al. made detailed investigations and observations on the 1904 flood of the Ishikari River. Based on these investigations, a flood control plan focusing on cutoff works was formulated, and those works were implemented for the half-century from 1910. This study reviews the effects of the flood in 1904, which served as the basis for the flood control plan, on the primeval Ishikari River Basin of the time, utilizing the results of investigations by Okazaki et al. We use two-dimensional flood flow numerical simulation to examine the effects of cutoff works. We also explain how the flood control plan had the effect on the basin development.

Key Words: Ishikari River, Flooding of a primeval river, Okazaki Bunkichi's flood study, Early flood control plan, Cutoff works, Flood flow numerical simulation

\section{1.はじめに}

石狩川は北海道央部を流れる道内最大の一級河川であ る. 現在，流域には札幌市や旭川市等の都市が発達し， 流域人口 313 万人と北海道の $57 \%$ 占める。.また，石狩平 野はわが国の穀倉地帯として重要な役割を担っている.

石狩川流域の開拓は，明治に入ってから始められた。 政府は屯田兵制度を導入するなどして積極的な移民を行 い，農地の拡大に努めた。その結果，30年後には流域人 口は30万人に増大した．移民による開拓が軌道に乗りか かった1898年(明治31年)に開拓が始まって初めての大洪 水が流域を襲った. この1898年(明治31年)洪水の汇濫区 域を図-1に示す。記録では溺死者数 112 名であり，石狩 川洪水史上最多である。この洪水が契機となって治水事 業のための本格的な治水調査が始められた。 その調査期 間中の1904年(明治37年)に洪水が発生した。北海道庁技 師岡崎文吉 ${ }^{1 ）}$ を始めとする技術者たちによって綿密な観 測が行われ，河道内流量や汇濫流量が調査された.この 結果を基に石狩川の最初となる治水計画が1909年策定さ れた.このとき, 計画流量は汇濫量を河道で受け持つこ とを前提として算出することによって $8,350 \mathrm{~m}^{3} / \mathrm{s}$ と定めら れた. 以来1981年(昭和56年)の大洪水が発生するまでの 70年間, この計画流量は大きく変わることはなかった.
石狩川の治水事業開始当時，本川の高水工事は捷水路 工事が主体であった。1910年から1969年にかけて全部で 29か所施工され，流路延長は58km短縮された ${ }^{2)}$. 特に, 初期に施工された下流部5箇所の捷水路工事だけで $22 \mathrm{~km}$ 短縮された.このうち最初に施工されたのが最下流部に 位置する最大規模の生振捷水路 (1931年通水開始)であり, 他4か所の捷水路も1933年までに通水を開始している.

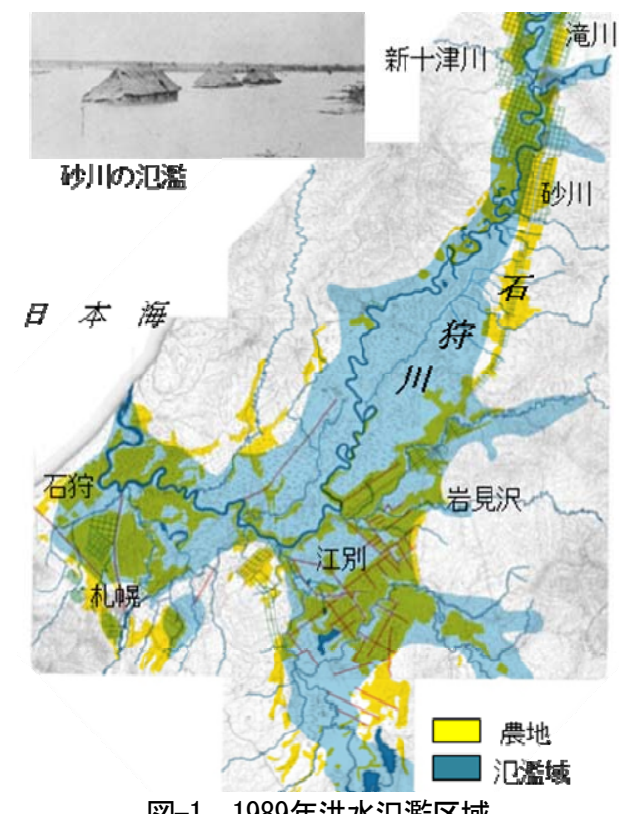

図-1 1989年洪水汇濫区域 
従来石狩川の捷水路工事の評価は一次元解析によって, 流出が早まりピーク流量が増加するが水位は低下寸る効 果が明らかにされている3．しかしながら，原始状態の 河川では図-1のように洪水流は河道も汇濫原も関係なく 流下していたと考えられ, 初期の捷水路工事の評価を行 う際に汇濫現象を無視することはできない. 本研究では, より具体的な効果として汇濫現象への捷水路工事の影響 を検討することを目的とする. 岡崎文吉らによる1904年 (明治37年)洪水の観測結果を再度整理し，平面二次元不 定流計算を行うことによって原始状態の石狩川流域にお ける汇濫形態を検証寸るとともに，治水事業初期に行わ れた下流部捷水路工事の汇濫形態変化に対寸る影響を検 討する. さらに，この捷水路工事がもたらした波及効果 について, その後の流域の土地利用状況等から検証する.

\section{2. 石狩川流域の開拓と1898年 (明治31年) 洪水}

石狩川治水史)等の資料によると，1869年以降，移民 政策により屯田兵や民間開拓者は札幌を起点として，江 別, 美唄, 滝川, 新十津川等の水はけの良い上流部一と 開拓を拡大していった。 さらに湿原地帯であった石狩平 野内部への開拓も排水路建設により地下水位を低下させ ながら農地を拡大していった. 多くの困難を乗り越え, 開拓が軌道に乗り農地が拡大してきた1898年 (明治31 年) 9月7日に未會有の大洪水が発生した. 札幌測候所で は観測降雨量 $157.6 \mathrm{~mm} / 3$ 日 $^{4)}$ と記録されている。この洪 水による浸水面積は田1,156町，畑49,964町，浸水家屋 16,347戸，流失家屋1,041戸，潰屋969戸，半潰屋285戸， 溺死人112名であり ${ }^{2)}$ ，上流部の滝川や新十津川から下 流部の札幌や石狩に至るまで石狩平野一面が浸水し，洪 水継続時間も1週間と長期に亘り，被災者は水と食料に 窮したことが記録として残っている.

この1898年(明治31年)洪水によって多くの移民者が離 散し，これから入植する開拓者の意欲を阻害することと なった. そのため, 官民双方から治水を求める声が高ま り, 1力月後には廣井勇, 岡崎文吉等北海道庁の技術者 らを中心とした「北海道治水調査会」が発足するなど5)， この洪水を機に石狩川の治水調査が開始された.

\section{1904年(明治37年) 洪水の観測1)}

1898年(明治31年)洪水を受けて一刻も早い治水工事と して下流の蛇行部を日本海まで直線化する掘削工事を流 域住民から要請されたという記録が石狩川治水請願書(6) に残っている. しかし, 治水調査会4) は全体計画無しに 部分工事を行ってもむしろ弊害を招くとして調查に専念 している. 当時治水計画のために開始された調查は三角 測量, 河川縱横断測量, 地形測量, 降雨量, 河川水位お
よび流量等であった．全洪水量を把握するため汇濫原測 量も行われた. 調査中の1904年(明治37年)に発生した洪 水は，降雨量も札幌測候所で $177 \mathrm{~mm} / 3$ 日) $^{4}$ と1898年 (明治 31年) 洪水と同規模であり, 図-2に示寸氾濫域からも 同様の氾濫状況であったとされる. 岡崎らは, この洪水 発生時には既に石狩川本川4ヶ所, 支川雨竜川, 空知川 および夕張川の水位流量観測所を設置しており, 各所の 水位流量曲線を作成している。.また石狩川本流には21か 所の水位観測線を設置し，汇濫量を把握するために汇濫 原の横断測量を行う等の事前調査を行っていた. これら の観測箇所を図-2に示寸。この洪水発生時，7月9日18時 から17日18時までの8日間で13回にわたってほぼ同時に 各観測地点において水位観測が行われた. 図-2中の観測 模式図に示したように, 各観測箇所では水位から河道内 および河道外の流下断面積が求められ, さらに流量観測

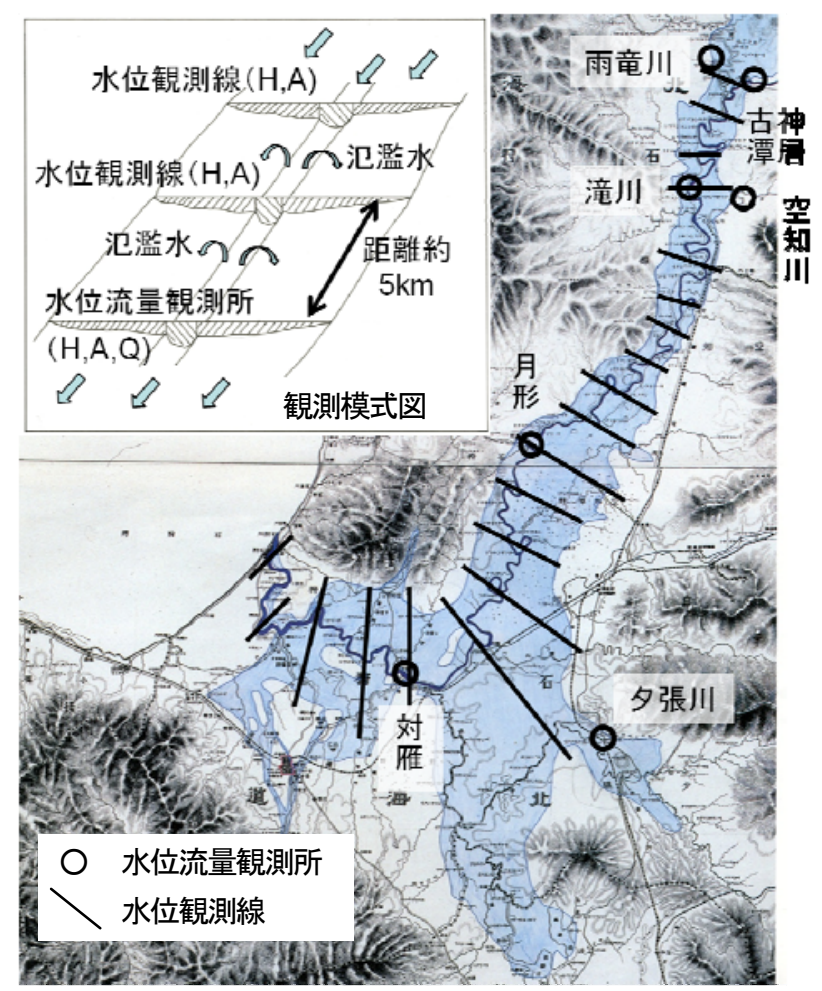

図-2 1904年 (明治37年) 洪水汇濫域および観測箇所

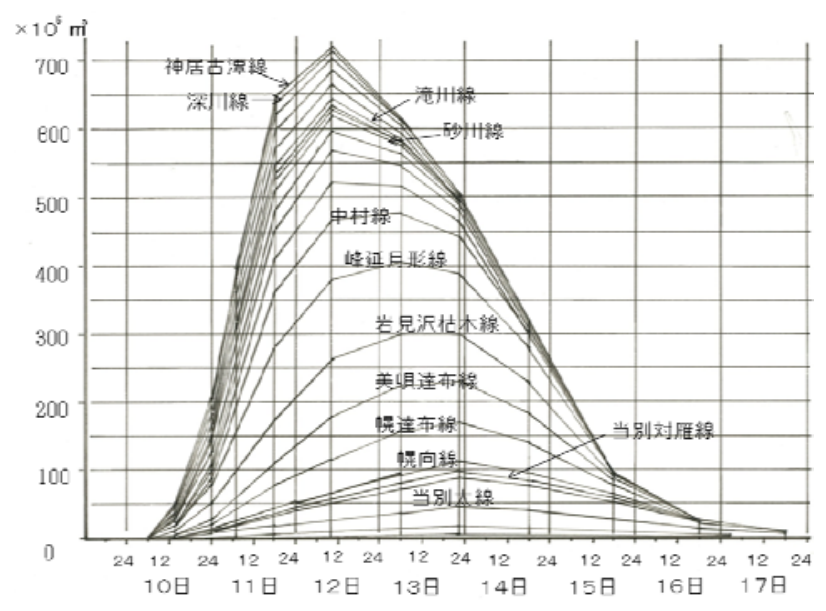

図-3 洪水時石狩川河道外氾濫量図 


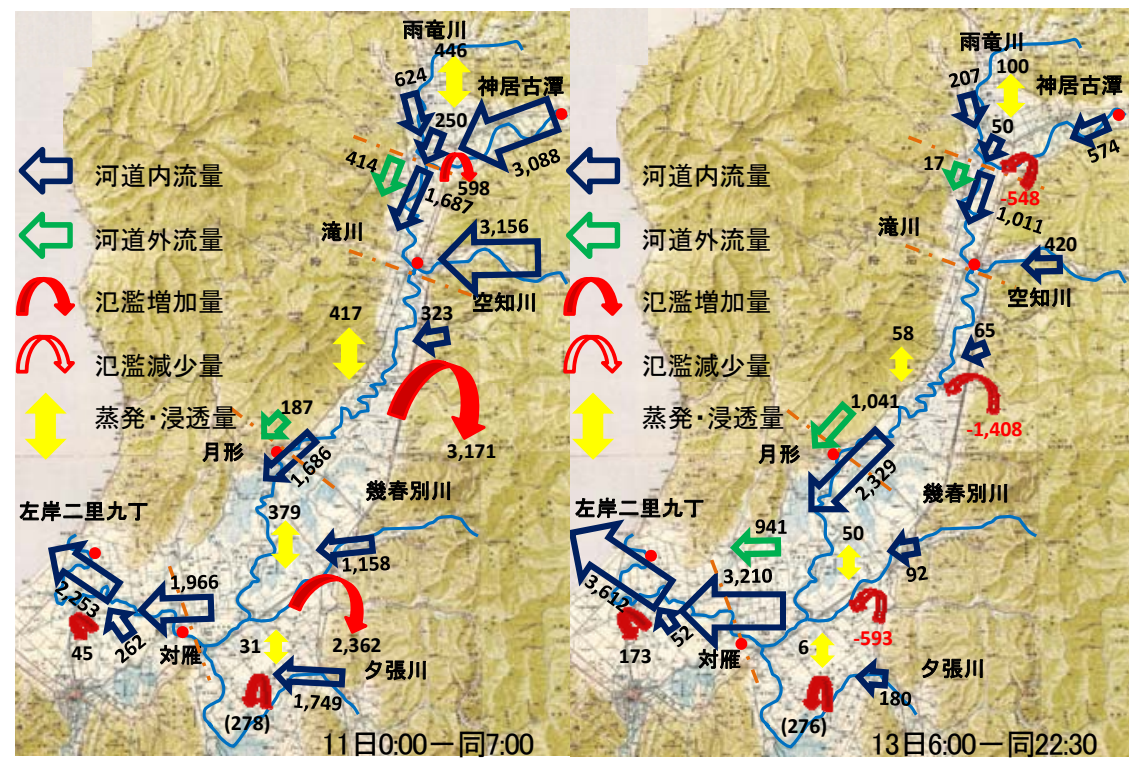

図-4 1904年(明治37年) 洪水における河道内外の流量

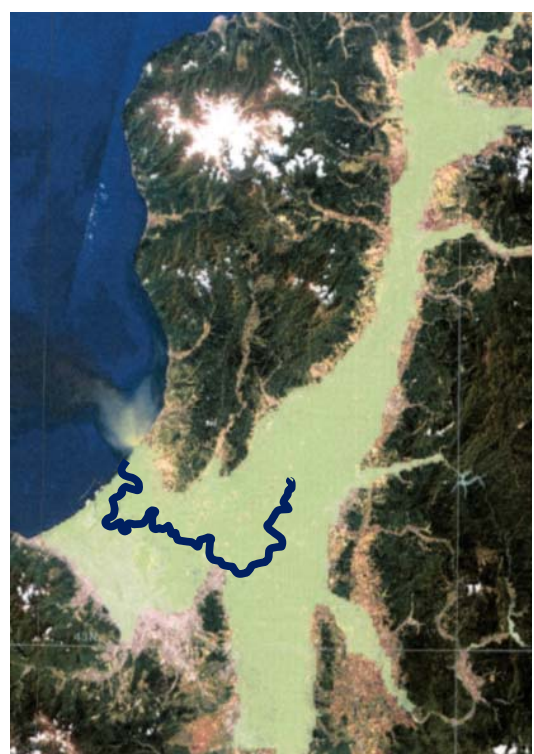

図-5＼cjkstart計算範囲と旧河道位置
地点では水位流量曲線から河道内流量が求められている 観測された流下断面積に測線間の延長を掛け合わせるこ とによって各観測時刻における各測線間での汇濫量が図 -3のように求められている.

水位流量観測地点のうち洪水流が石狩平野に流入する 本川上流地点の神居古潭, 雨竜川, 空知川および夕張川 の観測所はいずれも地形特性上河道外汇濫のない地点が 選定されており，これらの地点を通過した洪水流は河道 内流量のみで算出される. その他の本川3箇所の水位流 量観測地点 (滝川, 月形および対雁)では河道内流量と河 道外流量が算定されている.これらの水位流量観測地点 間の汇濫量は前出の各水位観測線間における汇濫量を対 象区間において累計することで収支を求め，その収支の 平均値として汇濫増加量が算出される. ここで残流域流 出量は面積当たりの比流量から算定され, 蒸発・浸透量 は総流出量の $12 \%$ とて算定されている. このようにし て, 各地点における各観測時刻間の「河道内流量」,

「河道外流量」および「氾濫増加量」が観測值として整 理されている. 整理されている観測值の例として11日 0:00一同7:00および13日6:00一同22:30における各流量を 図-4に示寸．前者(図左側) は神居古潭および空知川にお いてほぼ流量最大時の観測值であり, この時, 神居古潭 と空知川以外の地点では河道内流量がそれほど増加して いないにも関わらず，全域にわたって汇濫量が増加して いる. これは上流側で一度氾濫した洪水流の多くがその まま氾濫原を流下していたと考えられる．また後者(図 右側) は下流の対雁地点において流量最大時の観測值を 示寸。この時既に上流では河道内流量が減少し，本川流 域の汇濫水は河道に流入しているが, 夕張川流域(現在 は千歳川流域)では依然汇濫量が増加している.

これらの観測值を用いて河道設計の計画流量が設定さ れた. 各流量観測所において河道内外流量に観測地点よ り上流の全氾量を観測地点の加えることで，氾濫しない
と想定した観測時刻毎に求めると，対㕍地点で11日0:00 一同7:00 (図-4左側に該当)において最大值8,350 $\mathrm{m}^{3} / \mathrm{s} （=$ 河道内流量 $<1,966 \mathrm{~m}^{3} / \mathrm{s}>+$ 上流の汇濫量 $<598 \mathrm{~m}^{3} / \mathrm{s}+$ $3,171 \mathrm{~m}^{3} / \mathrm{s}+2,362 \mathrm{~m}^{3} / \mathrm{s}+278 \mathrm{~m}^{3} / \mathrm{s}>）$ となり，この最大值が 計画流量として設定された。 この值はその後長年にわた り計画高水流量として用いられ，1965年の計画改定時に 1899年～1962年の降雨等から $1 / 100$ 年確率流量として計 画基本高水のピーク流量が9,300 $\mathrm{m}^{3}$ 秒2) と設定されるが, 当初の值 $\left(8,350 \mathrm{~m}^{3} / \mathrm{s}\right)$ と大差なく, 当時の算定方法が妥 当であったと理解できる. 詳細な汇濫流観測を行い，そ の観測值を河道内流量に加えて設計していた当時の計画 はその後の石狩川を先見したものであったと評価できる.

\section{1904年(明治37年) 洪水の再現計算}

\section{(1) 計算概要}

岡崎らの観測值を用いて，当時の原始状態における石 狩川の汇濫流計算をRIC-Naysによる平面2次モデル7を用 いて行った. ここで基礎式は次式で表わされる.

$$
\partial h / \partial t+\partial(h u) / \partial x+\partial(h v) / \partial y=0
$$

$$
\begin{gathered}
\frac{\partial u}{\partial t}+u \frac{\partial u}{\partial x}+v \frac{\partial u}{\partial y}=-g \frac{\partial H}{\partial x}-\frac{\tau_{x}}{\rho h}+v\left(\frac{\partial^{2} u}{\partial x^{2}}+\frac{\partial^{2} u}{\partial y^{2}}\right) \\
\frac{\partial v}{\partial t}+u \frac{\partial v}{\partial x}+v \frac{\partial v}{\partial y}=-g \frac{\partial H}{\partial y}-\frac{\tau_{y}}{\rho h}+v\left(\frac{\partial^{2} v}{\partial x^{2}}+\frac{\partial^{2} v}{\partial y^{2}}\right)
\end{gathered}
$$

ここで， $x$ おびyは直角座標軸，uおよびvはそれぞれ $x$ およびy方向の平均流速， $h$ は水深， $H$ は水位， $\tau_{x}$ および $\tau_{y}$ はそれぞれxおよびy方向の河床抵抗である. 上式は直行 座標系における基礎式であり，本計算では上式を一般座 標系に変換して解くことで汇濫流の挙動を計算している. 粗度は河道, 汇濫原の区別なく 0.03 として計算した. 


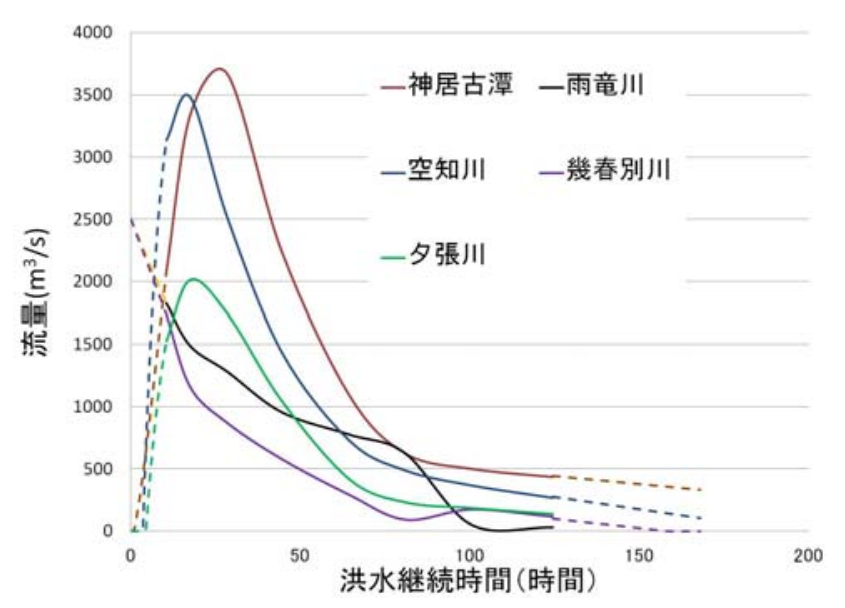

図-6＼cjkstart計算に用いたハイドログラフ

計算の範囲は図-5に示す石狩平野（緑）とし，南北 $110 \mathrm{~km}$ ，東西 $40 \mathrm{~km}$ 範囲に対して，現況のLPデータを用 いて平均 $220 \mathrm{~m}$ 格子データを作成した．現在の石狩川お よび主な支川は人工的に掘削され堤防も設置されている ことから，現在の河道部の地盤データを取り除き，替わ りに周辺の地盤高さで補間した值を用いた．当時の石狩 川の河道部については，1910年の謄本地形図より平面形 状(図-5中の青線)を，また1932年測量の河川横断測量成 果から地盤高を推定し格子データとして与えた。

流量流入地点は神居古潭, 空知川, 夕張川および幾春 別川とした. 神居古潭地点からは上流部からの流入とし て, 神居古潭および空知川の流量観測值の合計を流入条 件とした. 空知川および夕張川地点からは各地点の流量 観測值を用い，幾春別川地点からは空知川一夕張川間に おける残流域流入量の観測值を用いた。 各地点における 流量を図-6に示寸。実線は岡崎らによる観測結果であり, 点線は観測值の無い洪水初期と終息期において観測値を 補間した值である。洪水開始の10日8時から洪水継続時 間176時間後の 17 日16時までの計算を行った。下流端は 日本海側であり自由流出とした.

\section{（2）計算結果および原始状態の石狩川氾濫形態}

平面2次元計算の結果を図-7に示寸. 図-7は浸水深の コンタ図を示している．図中のピンクおよび黒のパー ティクルはそれぞれ石狩川本川および夕張川から流入す る水の流れを表している。

図-7の左図は45時間後 (12日5時) の汇濫の状況である. 中上流部の汇濫範囲が最大で, 洪水のピーク時と考えら れる. 図-2の汇濫図と比較すると, 浸水範囲はほぼ一致 しており，再現計算は妥当だと考えられる．この時点で は夕張川からの流れは石狩川に流下できず千歳川一逆流 している. 夕張川流域（現在は千歳川流域）は標高が比 較的低く, 洪水流は滞留しさらには石狩川からも逆流す る地域である，中央の図は60時間後（12日20時）の汇濫 の状況である. 左図から15時間経過し, 中流部の汇濫域 は減少しているのに対し，下流部では汇濫区域が拡大し ている. 夕張川の洪水流は依然石狩川、合流できず逆流 している. 右図は176時間後（17日16時）の汇濫の状況 である. 石狩平野への洪水流の流入は殆どなく, 下流部 の汇濫域も減少しているが夕張・千歳川流域ではまだ汇 濫が続いている.この地域は現在の千歳川中下流部であ るが，標高が低く現在も水害を受け易い地域なっている.

\section{1909年作成の治水計画と捷水路工事の効果}

\section{（1）石狩川治水計画調査報文 ${ }^{8)}$}

1904年(明治37年)洪水観測後，1909年に石狩川の始め ての治水計画が「石狩川治水計画調查報文」として岡崎 文吉により策定された。計画は江別より下流部の蛇行部 分を直線で掘削する放水路方式とし，低水時の航路維持 と排水機能維持のために従来の河道を維持するもので あった. 放水路方式が提案されたのは現状の河道を残す ため工事量が少なく経済的で, かつ当時重要な交通手段 であった舟運の航路を維持するためとされている. しか
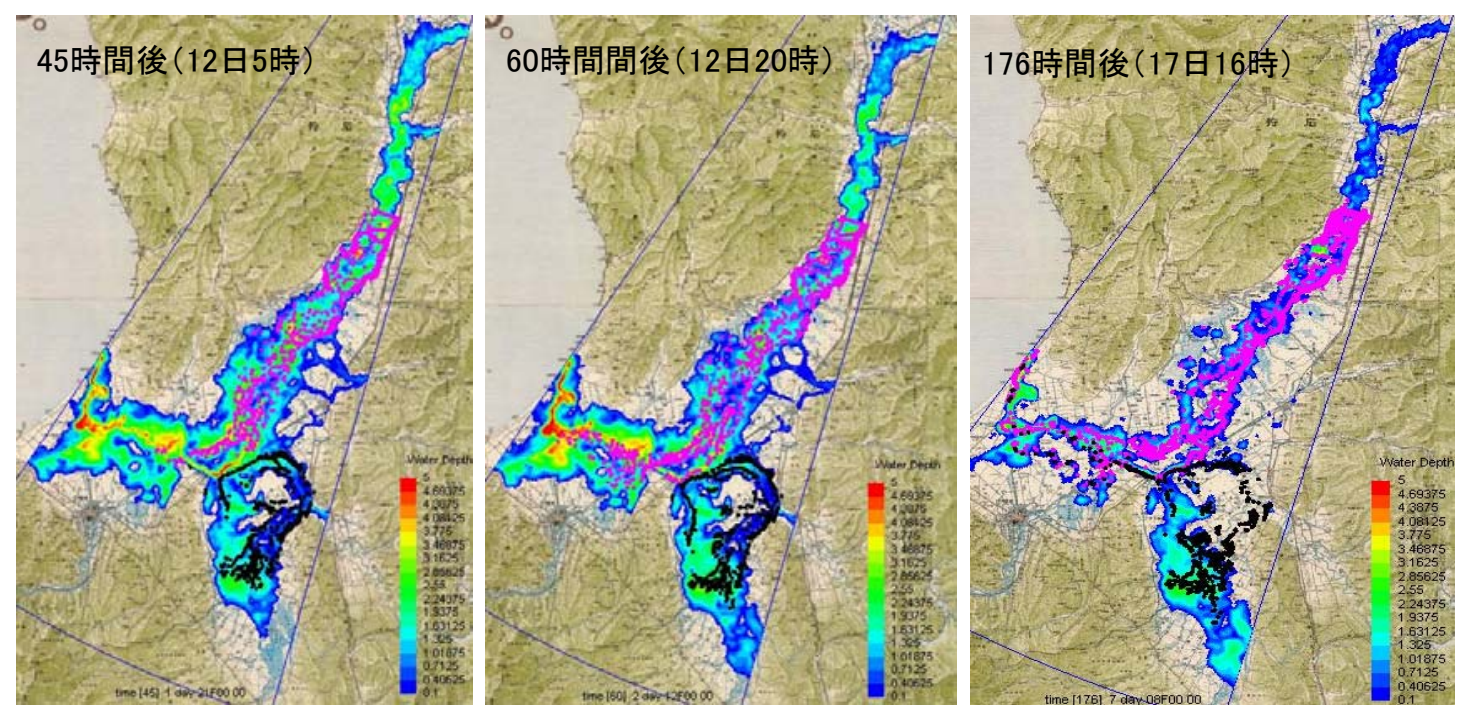

図-7 1904年(明治37年) 洪水再現計算結果 


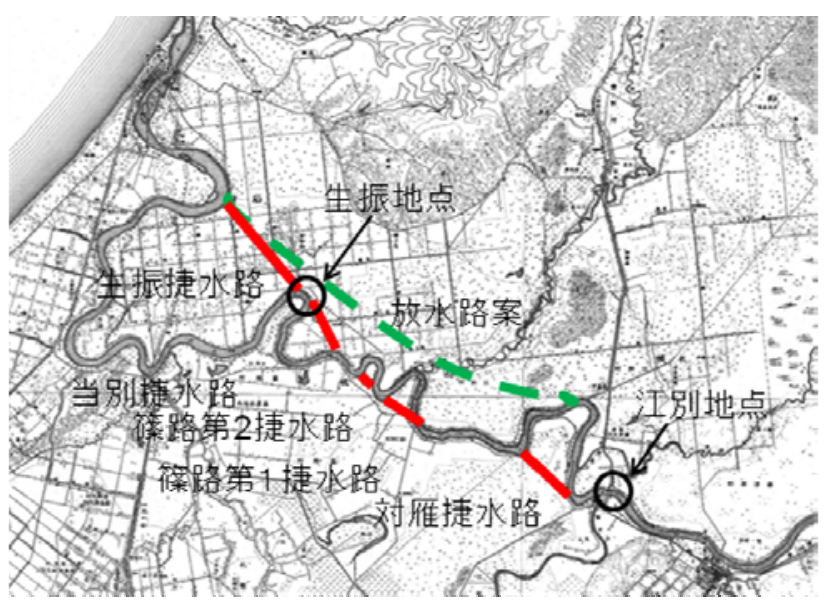

図-8 石狩川の第一期捷水路工事個所

し，1917年に岡崎は高水工事について図-8に示すように, 放水路方式加捷水路方式へと計画を変更した。「放水 路と在来水路の 2 条の維持は, 防御線の延長が増加し, 将来の維持の係累上, 直流式が永遠の利益となる」9)こ とを理由としている.

1918年に石狩川で初めての本格的な治水工事が最下流 部の生振捷水路から開始され2)，第1期工事として1933年 までに下流部の5捷水路が通水した．放水路案および第1 期工事個所を図-8に示寸．河口から対雁地点まで46km の河道延長を $24 \mathrm{~km} に$ 短縮した.

\section{（2）下流部捷水路工事の効果}

これら5ケ所の捷水路工事の効果を具体的に明らかに するために前章と同様に平面二次元汇濫流解析を行った. 前章で用いた計算格子に対して捷水路工事で掘削された 箇所と捷水路沿の築堤部を格子デー夕に反映させた．石 狩川上流部や支川からの流入量, 汇濫原の粗度等は再現 計算と同一の值を用いた。

図-9に洪水開始から45時間後（12日5時）および60時 間後（12日20時）の氾濫状況を示す. 図-7と比べると， 捷水路区間左岸側（札幌市北部）で著しく汇濫域が減少 している．これは後述するように捷水路による排水効果 と築堤による直接的な効果であると考えられる. また夕 張川の汇濫地域については捷水路工事後も大きな変化は みられない。しかし，図-9では洪水開始60時間後の時点 で既に夕張川からの洪水流が石狩川本川に合流しており， 夕張川の汇濫流が本川へ流れ込むタイミングが大幅に早 くなっていることがわかる. 第一期捷水路工事終了間際 の1932年洪水の浸水図（図-10）を1904年洪水（図-2） と比べると，この地域では氾濫域が大きく減少している. 次に, 生振と江別地点の水位変化について捷水路工事 前後の比較を図-11に示寸．図より捷水路工事区間直上 流の江別地点では工事後に最大水位の值が低下しただけ でなく流量減少時に工事前と比べて大幅に水位が低下し ており，そのため汇濫流が本川に流れ込むタイミングが 早まっていると考えられる. 具体的には捷水路工事前後
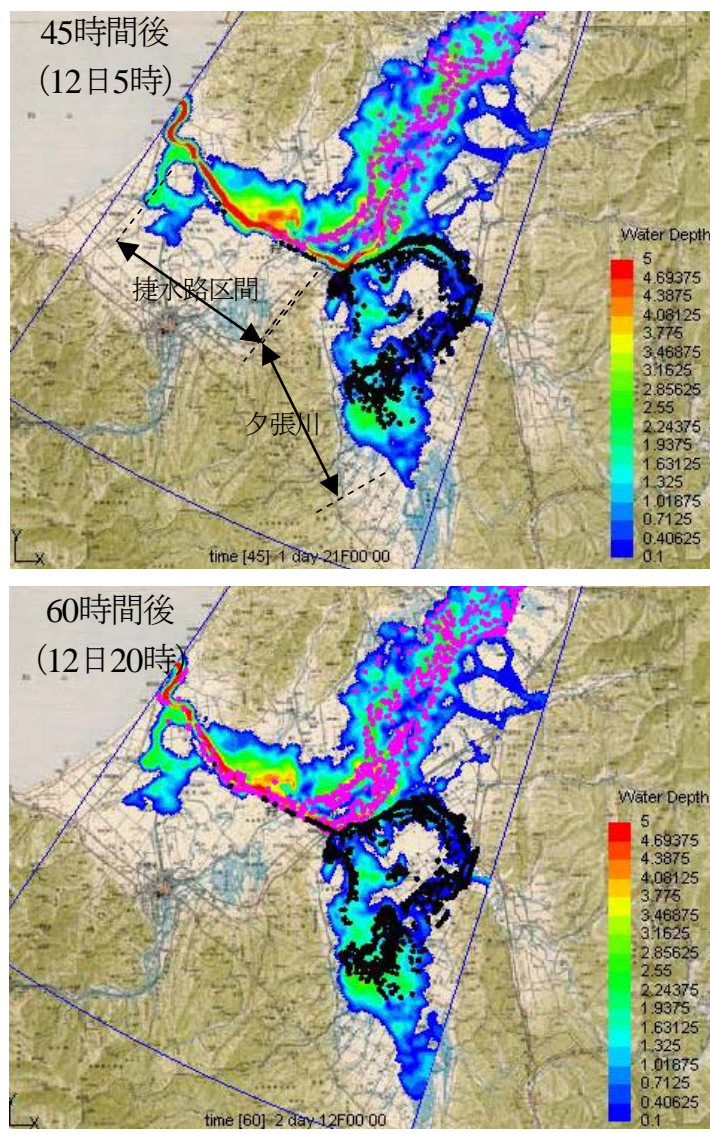

図-9 捷水路工事後の汇濫状況（計算結果）

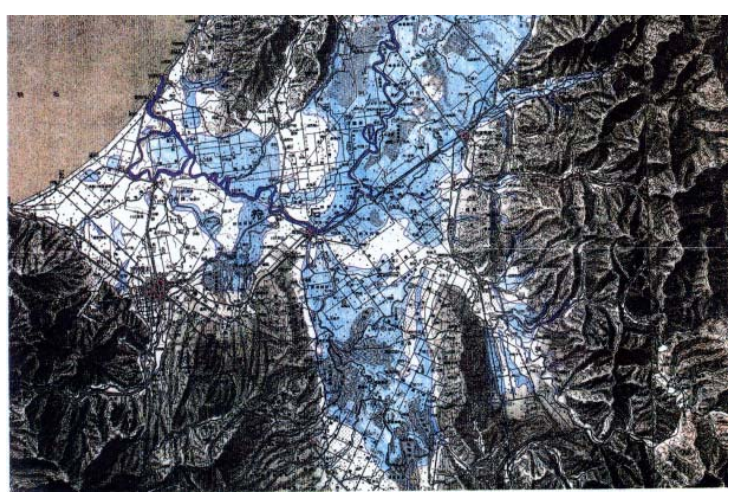

図-10 1932年洪水汇濫域図

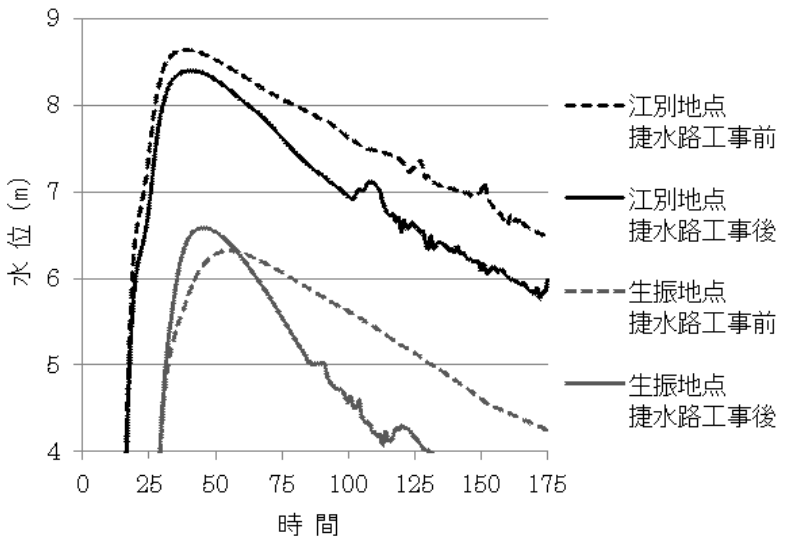

図-11 江別 - 生振地点の水位の比較 


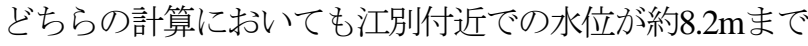
低下寸ると夕張川流域の汇濫流が本川に流れ込み始める 結果となっており，捷水路の効果で本川の水位低下が大 幅に早まり，これに対応して図-9に見られるように氾濫 流の終息も早まる過程が合理的に再現されている. 本研 究の計算によると, 夕張川流域から汇濫流が本川に流れ 込夕始める時刻は捷水路工事前後で約12時間短縮される という結果となった．また，江別付近の地盤高さがおお よそ7m位であり, 図-11をみると, この付近で水位が7 mに低下寸るまでの時間が工事前後で50時間程度も短縮 されていることがわかる.

また，生振地点では捷水路によりピーク到達時間が早 くなり，ピーク水位も $0.3 \mathrm{~m}$ 上昇している.このピーク位 の上昇に対しては捷水路掘削と同時に行われた築堤によ り氾濫が抑制された影響であると考えられる。したがっ て, 捷水路対象区間の左岸側で汇濫域が減少したのは工 事における築堤の効果であると考えられる，また，ピー ク後は大きく水位が低下し洪水継続時間が大幅に短縮し ており, 前出と同様に上流および周辺の洪水の終息を早 める効果のあることがわかる.

\section{6. 最初の治水計画による捷水路工事の波及効果}

石狩川初の治水計画による捷水路工事が流域にどのよ うな効果を及ぼしたのか考察を行った. 図-12に治水事 業開始以前の1904年洪水の氾濫域，捷水路，札幌の治水 事業開始以前の住宅地域，現在の住宅地域を示寸.

札幌は石狩川の氾濫を避けるように南側の豊平川の扇 状地の扇央から開拓が始まった．扇央より南は山地であ り可住地は狭小で，北部は図に示寸ように低平から石狩 川の汇濫地域であり開発は困難であった. 1887年に南西 部山地からの洪水流入を避けるために(1)新川(図-12中) が開削された. しかし北部低平地への石狩川からの汇濫 は解消できなかった，石狩川の(2)捷水路工事は, 前章に 示すように石狩川左岸の札幌北部の汇濫を大きく減少さ せる効果があった．さらに1941年には水位の低下した捷 水路上流部に合流寸る(3)豊平川新水路が開削され豊平川 からの汇濫が解消される．その結果，札幌北部低平地は 豊平川流域から切り離され，札幌の中小河川は洪水時で も水位の低い石狩川旧川に流下寸ることとなり，治水安 全度は大幅に向上し北部に宅地が広がった．さらに1982 年には旧川と日本海を結ぶ(4)石狩放水路が完成し，札幌 北部は完全に石狩川流域から切り離され，直接日本海に 注ぐ独立した流域となった。 これにより札幌北部におけ る洪水時水位は一層低下し, 札幌北部は洪水に強い地域 となった. 石狩放水路完成後, 宅地の進出は促進され, 現在では道都札幌の発展を支える地域となっている. 最 初の治水計画による捷水路工事の波及効果と考えられる.

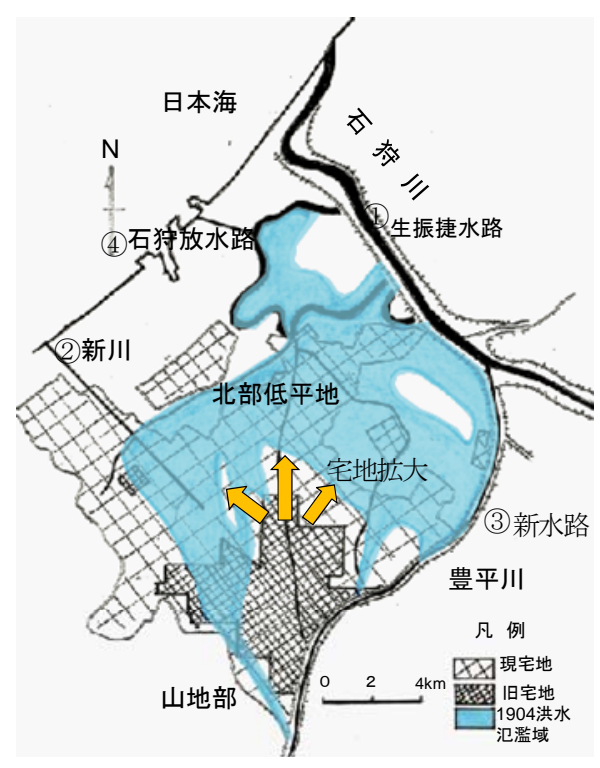

図-12 札幌市の発展

\section{7. おわりに}

本研究では，石狩川治水事業初期に行われた捷水路工 事の効果について汇濫現象一の影響を検討寸るために, 岡崎文吉らによる1904年(明治37年)洪水の観測結果を再 度整理し, 平面二次元不定流計算によって原始状態の石 狩川流域における汇濫形態を良好に再現するとともに, 治水事業初期に行われた下流部捷水路工事の汇濫形態変 化に対する影響を検討し，捷水路工事によって汇濫流を 早期に流下させるという効果を具体的に示した. また, この捷水路工事のその後の治水事業に対寸る波及効果を 考察した. 1898年洪水時の石狩川流域の人口は30万人で あったが，2010年には313万人とほぼ10倍にまで発展し ている.1世紀以上も前に策定された初期の治水計画が 流域の発展の基礎となったものと評価できる.

\section{参考文献}

1）北海道開発局 : 石狩川治水の曙光-岡崎文吉の足跡-, 北海 道治水技術研究会, 1990 .

2）石狩川治水史編集委員会 : 石狩川治水史, 北海道開発協会, pp211, 1980.

3）品川守, 舘谷清, 山口甲 : 捷水路による洪水汇濫と洪水流 の変化 土木学会水工学論文集第36巻, 1992

4) 気象庁: 天気図, JMA WEATHER CHARTS Vol.02, 2005.

5）石狩川開発建設部：石狩川の流れ，2000.

6）坂本直寛, 他 2 名 : 石狩川

7）治水請願書，1905年11月.

8）田中甫幸, 清水康之, 木村一郎, 岩崎理樹 : 札幌市に おける河道改修と汇濫形態の変化，水工学論文集第55 巻, pp895-900, 2011.

9）岡崎文吉 : 石狩川治水計画調査報文，1909.

10）山口甲, 品川守, 関博之：捷水路, 北海道河川防災セン ター, 1996.

(2011.9. 30受付) 